\title{
State of the Environment
}
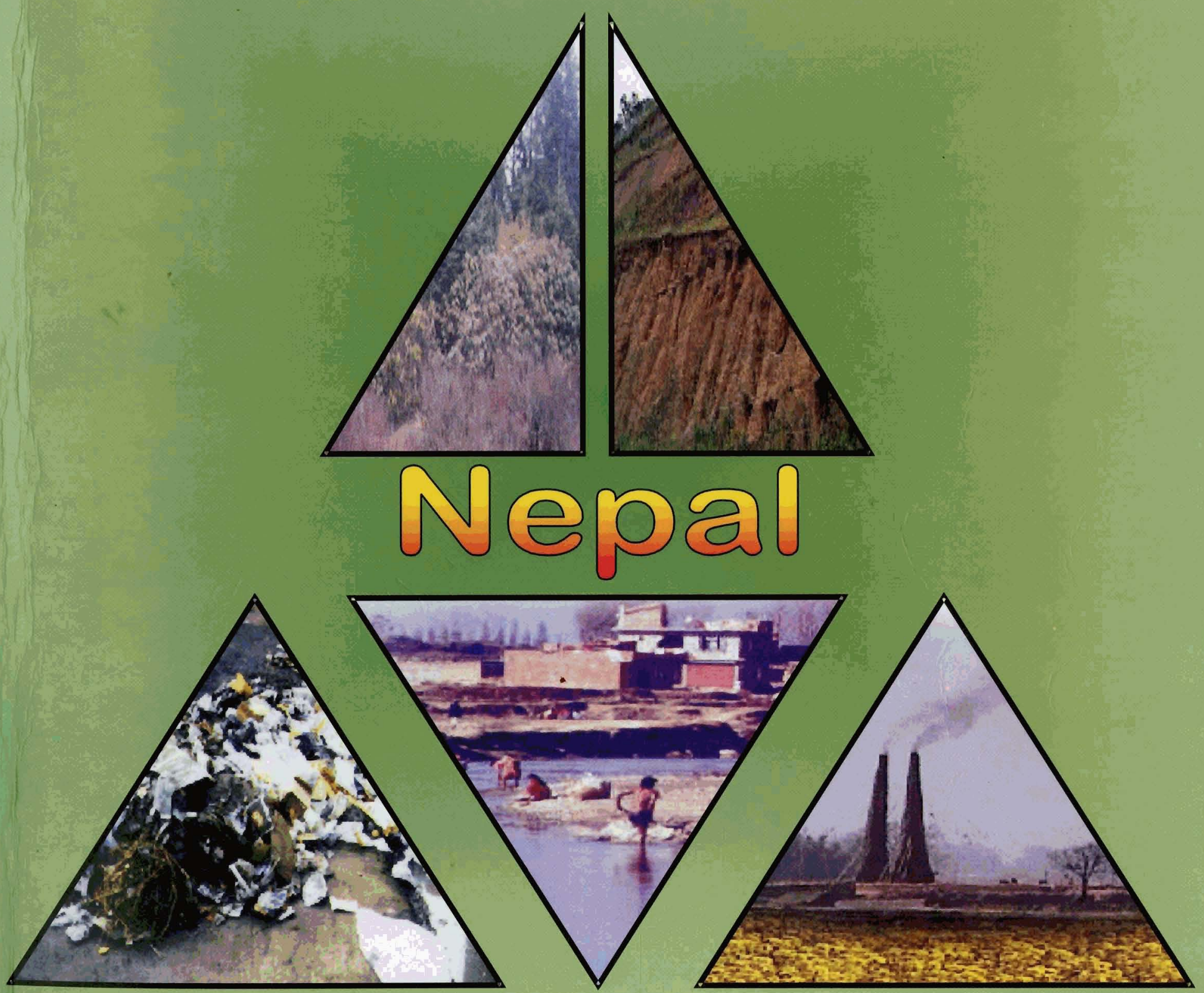

\section{1}

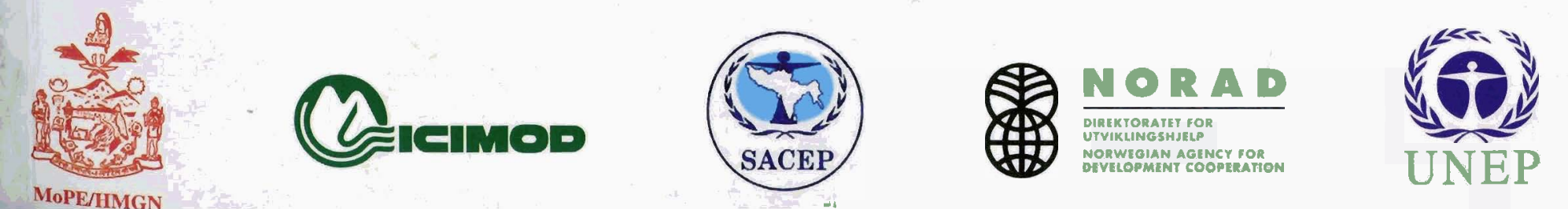




\section{Nepal: State of the Environment 2001}

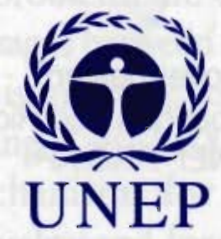

In collaboration with
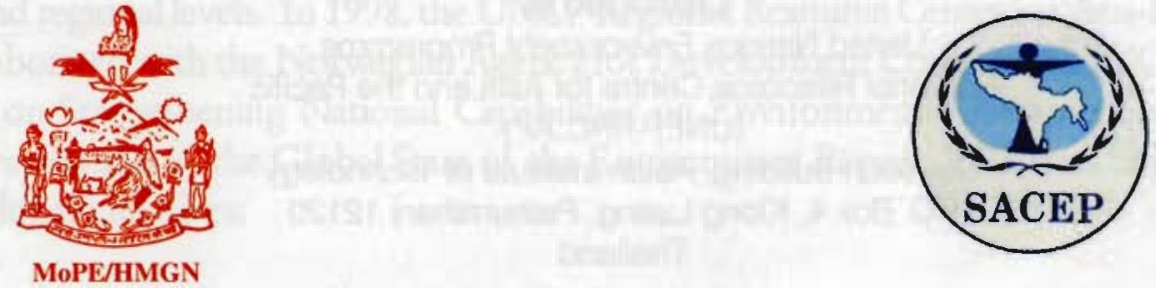

Qmennoo 
This publication may be reproduced in whole or in part and in any form for educational or non-profit purposes without special permission from the copyright holder, provided acknowledgement of the source is made. UNEP would appreciate receiving a copy of any publication that uses this publication as a source. No use of this publication may be made for resale or for any other commercial purpose whatsoever without prior permission in writing from the United Nations Environment Programme.

\title{
DISCLAIMER
}

The contents of this volume do not necessarily reflect the views or policies of UNEP or contributory organisations. The designations employed and the presentations do not imply the expressions of any opinion whatsoever on the part of UNEP or contributory organisations concerning the legal status of any country, territory, city or area or its authority, or concerning the delimitation of its frontiers or boundaries.

\author{
Cover design \\ Purna Chandra Lall Rajbhandari and Ric Dennis A. Canullas \\ UNEP-RRC.AP \\ Layout \\ Dharma R. Maharjan \\ Sushil M. Joshi \\ ICIMOD Publications' Unit
}

\author{
Distributed by \\ United Nations Environment Programme \\ Regional Resource Centre for Asia and the Pacific \\ (UNEP-RRC.AP) \\ Outreach Building, Asian Institute of Technology \\ P.O. Box 4, Klong Luang, Pathumthani 12120 \\ Thailand
}

Nepal: State of the Environment 2001 


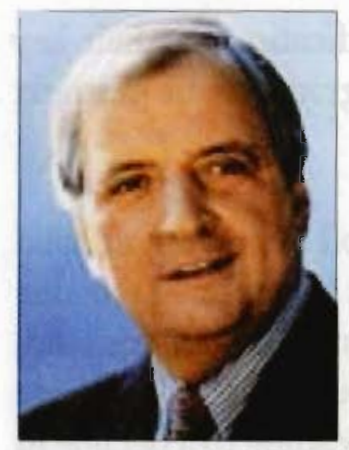

Foreword

Executive Director

UNEP

The Rio Earth Summit in 1992 formulated an action plan, Agenda 21: a multifaceted process to address he full range of development and environmental issues involving participation of governments, international organisations, and major groups in the quest for sustainable development.

The publication of the Global Environmental Outlook series, GEO-1, followed by GEO-2000, the Millennium Report on the Environment, involved a participatory assessment process to review the state of the world's environment and to chart a new process for global environmental policy. The diversity and magnitude of environmental problems are outlined, with a call for more complete and precise analyses of the poorly understood linkages between human actions and environmental outcomes. Although the number of policy responses is growing, low priority continues to be afforded to the environment in national and regional planning. GEO-2000 stressed the need for the development of more comprehensive and long-term mechanisms for monitoring and assessing the effects of environmental policies on environmental quality and for more integrated policy-making and actionbased programmes to serve the needs of the people.

The United Nations Environment Programme (UNEP) is mandated to produce a Global State of the Environment Report in 2002 (GEO-3) for the 2002 Earth Summit, i.e., Rio + 10, and this global assessment will be enriched by producing State of Environment (SoE) reports at the national, subregional, and regional levels. In 1998, the UNEP Regional Resource Centre for Asia-Pacific (UNEPRRCAP) collaborated with the Norwegian Agency for Development Cooperation (NORAD) to carry out a process on Strengthening National Capabilities on Environment Assessment and Monitoring towards the Preparation of the Global State of the Environment Report 2002, thus linking national to regional and global initiatives.

This National State of the Environment (SoE) Report of Nepal is the first of seven national reports from the above process, focusing on two Asia-Pacific subregions, namely South Asia (Bangladesh, Bhutan, Maldives, Nepal, and Sri Lanka) and the Greater Mekong Subregions (Laos and Vietnam). The Ministry of Population and Environment (MoPE), the national implementing agency in Nepal, has played a very crucial role in carrying out this participatory assessment process in soliciting input from various government sectoral agencies. Around 70 agencies and 150 individuals were involved in the process. With the substantive support from the International Centre for Integrated Mountain Development (ICIMOD), the designated national collaborating centre in Kathmandu, and regular feedback from the South Asia Cooperative Environment Programme (SACEP), this assessment exercise has been successful and instrumental in providing significant input to the ongoing South Asia SoE preparation. It aims at providing guidelines for environmental action planning, policy setting, and resource allocation for the coming decades, based on a sound analysis of the state of, and trends in, the nation's environment.

Five key priority issues for the environment of Nepal have been identified through a consultative process and analysed following a 'pressure-state-impact-response' (PSIR) analytical framework. The 
same process will be followed by the other six countries, leading to the identification of their key environmental issues. These can then be addressed through action-based programmes in the next phase of the planning process.

The five key environmental issues identified for Nepal are forest depletion, soil degradation, solid waste management, water quality, and air pollution. The forest area is declining at an alarming rate due to high demand of fuelwood, the main source of fuel in the country, and forest clearance for land, leading to soil erosion, landslides, floods, and loss of biodiversity. Nepal's mountains and hills are inherently vulnerable to landslides and soil erosion which cause soil degradation, leading to a decline in crop production. Solid waste management problems have arisen because of the introduction of plastic materials and changing consumption patterns, especially in urban areas. Water quality, particularly in rivers and lakes near urban areas, is deteriorating due to unregulated discharge of domestic and industrial effluent, and the health of the nation's people is compromised by both inadequate waste-water treatment and insufficient supplies of potable water. Air quality, particularly in urban areas, is deteriorating due to increases in vehicular traffic and air-polluting industries, while rural inhabitants are vulnerable to respiratory diseases because of burning fuelwood in poorly ventilated houses.

This SoE assessment for Nepal provides a sound basis for the development of action plans, the next stage of the planning process, as we enter the new millenium. The report aims to provide concrete guidance for action planning, policy setting, and resource allocation for the coming decades to improve the state of the environment of Nepal and the welfare of her people.

UNEP will continue to provide leadership in the region for the preparation of environmental assessment reports at national, subregional, and regional level and the capacity building necessary to support these assessment activities.

Klaus Töpfer

Under-Secretary General, United Nations and

Executive Director, United Nations Environment Programme

26 March 2001 


\section{Former Secretary Ministry of Population and Environment, Nepal}

Nepal is rich in various natural resources. Harnessing these resources can prove to be instrumental for the country's development. However, exploitation of these resources has to be carried out in a way that does not destroy the environment of the country. Thus, sustainable development and preservation of the natural environment have become challenges for today's Nepal.

Meeting such challenges requires evaluation and assessment of the status of the environment on a regular basis. A sound legal framework for management of the environment is equally important. There is no strong database on all aspects of the environment and natural resources and, as a result, no assessment and evaluation of the status of the environment could be carried out in a systematic and scientific manner. This report endeavours to close these gaps.

In May 1999 an agreement was formally signed between the United Nations Environment Programme/ Environment Assessment Programme - Asia and Pacific (UNEP/EAP-AP, Bangkok)/South Asia Cooperative Environment Programme (SACEP-Colombo), and the Ministry of Population and Environment, His Majesty's Government of Nepal (MoPE - Nepal)/International Centre for Integrated Mountain Development (ICIMOD) for implementation of the project on 'Strengthening Environment Assessment and Monitoring Capabilities in Nepal - State of Environment Report'. The project aimed to augment the capacity of His Majesty's Government of Nepal to make accurate environmental assessments, improve decision-making for sustainable development, and establish a strong information network with a uniform data format.

This Nepal: State of the Environment Report 2001, highlighting the five keyenvironmental priorities of Nepal (forest, soil, solid waste, water, and air) has been prepared at an appropriate time. These priority issues are genuine and very relevant to the present day context of environmental development in Nepal.

This report, prepared with the generous financial support of the United Nations Environment Programme (UNEP) and the Norwegian Agency for Cooperation and Development (NORAD), will serve as a valuable input and will help planners, policy-makers, and decision-makers to develop plans and formulate policies for the sustainable development of natural resources in Nepal without compromising the environment.

The Ministry is grateful to Mr. Surendra Shrestha, Director of UNEP-EAP, for bringing this project to Nepal. It extends its thanks to Dr. Gabriel Campbell, Director General, Dr. Binayak Bhadra, Director of Programmes, and Mr. Pramod Pradhan, former Head of ICIMOD-MENRIS, as well as Dr. Bandana Kayastha Pradhan, national consultant-SEAMCAP project, for their sincere endeavours in the successful implementation of this project and timely completion of the report. The contributions of Mr. Basanta Shrestha, the Acting Head of the MENRIS Division of ICIMOD, and Ms. Bidya Banmali towards completion of the project are also duly recognised. Appreciation is also given to Mr. Janak R. Joshi, 
Joint Secretary, Mr. P. Kunwar, Under Secretary, and Mr. B. K. Uprety, Ecologist of this Ministry for their contributions towards the successful completion of this project. Last, but not least, the work of all those who have given their support to the project is also sincerely acknowledged.

Dr. Govind Raj Bhatta

Former Secretary

Ministry of Population and Environment

Kathmandu

March 2001 
The environment of Nepal and the Hindu Kush-Himalayan ( $\mathrm{HKH})$ Region, in which it holds a place of pride, is renowned for its beauty and benefits. The divine snow and forest-clad mountains attract pilgrims and tourists alike. The rivers provide power and water for hundreds of millions downstream.

But all is not well with Nepal's mountain environment. The towering ridges are holding in a brown cloud of pollution over South Asia. Many forest areas are disappearing. Water is becoming increasingly polluted. In short, this beautiful mountain environment is in danger - but to what extent and from exactly what sources? What is the real state of the environment in Nepal? This is the question addressed in this report.

A fundamental problem in determining the state of the environment and natural resources of Nepal and the countries in the Hindu Kush-Himalayan $(\mathrm{HKH})$ region is that available data are scanty and scattered. The lack of adequate and aggregate data makes it difficult to evaluate the status of the environment of individual countries, let alone of the region as a whole. Poor data also make it difficult to build a sound legal foundation and support wise decision-making for sustainable development and conservation of the environment.

The types of environmental problems and their magnitude vary considerably among the countries in the HKH region. This report, entitled Nepal: State of the Environment 2001, profiles the key mountain environment issues of Nepal: forest, soil, solid waste, water, and air. It is anticipated that the information contained in this report will not only help to design policies and programmes for the environmental conservation of Nepal but will also provide a framework for environmental management that can be used as a guideline for other HKH countries.

The immediate objective of this project - Strengthening Environmental Assessment and Monitoring Capabilities in South Asia and the Greater Mekong Sub Region (SEAMCAP) - was to contribute to the preparation of the Nepal report, which will also feed into the preparation of the Decadal 2002 Global State of Environment Report. The goals of the project were to strengthen capacity and assist the government in establishing a strong information technology base for data processing, modelling, and analysis requirements to support assessment and reporting and to improve the basis for addressing important, emerging environmental problems.

The Ministry of Population and Environment (MoPE) was the national focal point for this project. ICIMOD has served as the collaborating and facilitating centre for completing this project and associated activities. It extends its gratitude to the $\mathrm{MoPE}$ and other government agencies for their cooperation in the successful completion of this project report. The project was also assisted by the United Nations Environment Programme (UNEP), the South Asia Cooperative Environment Programme (SACEP), and the Norwegian Agency for Cooperation and Development (NORAD). 
Dr. Bandana Kayastha Pradhan, national consultant, SEAMCAP project, has been responsible for much of the successful preparation and production of this project report. ICTMOD extends its gratitude to her, as well as to Mr. Pramod S. S. Pradhan, former Head of MENRIS Division, for his full-hearted effort to make this project successful. The help of Mr. Basanta Shrestha, the current Head of MENRIS Division, is highly appreciated in carrying this project to its completion. Mr. Birendra Bajracharya, GIS Specialist, has helped not only in preparing maps but also in providing valuable comments and suggestions for the report. Similarly, Ms. Bidya Banmali has helped in various ways to complete the report. Other MENRIS staff members who assisted in the preparation of this report are Mr. Pradeep Mool, Mr. Sushil Pradhan, Mr. Sushil Pandey, Mr. Samjol Bajracharya, Mr. Govind Joshi, Mr. Anirudra Shrestha, Mr. Saishab Pradhan, Ms. Monika Moktan, Ms. Sheela Thapa, and Ms. Meghna Shrestha. Ms. Greta Rana is due special thanks for rearranging her work schedule and that of the Publications' Unit (Dr. A. Beatrice Murray, Mr. Dharma R. Maharjan, Mr. Sushil M. Joshi, and Mr. Asha K. Thaku) to prepare this report for printing on an extremely tight schedule. As the Secretary of MoPE, Dr. Govind R. Bhatta provided overall guidance and supervision as well as timely comments, suggestions, and encouragement for this report. The help provided by Mr. Janak R. Joshi, Mr. Purushottam Kunwar, $\mathrm{Mr}$. Batu K. Uprety, and Mr. Chiranjibi Gautam of MoPE is also acknowledged and highly appreciated. In addition to these, sincere thanks are due to all those experts, reviewers, core groups, and contributors whose names and designations are given in full in the Annexes to this report.

ICIMOD is particularly grateful to Mr. Surendra Shrestha, Director of UNEP-EPA/AP, for his initiative and guiding hand in developing and carrying this project forward. Mr. Varun P. Shrestha, Former Secretary of MoPE, and Dr. Madhav Ghimire, Former Joint-Secretary of MoPE, are thanked for their role in bringing the project to ICIMOD. The project report is enriched by the comments and suggestions of Dr. Ananda Raj Joshi and Mr. Pradyumna K. Kotta of SACEP, and Mr. Choudhury R. C. Mohanty and Mr. Purna C. L. Rajbhandari of UNEP/EAP-AP. Finally, ICIMOD expresses its thanks to all contributors and reviewers representing various organisations in Kathmandu, Nepal, as well as the core group of participants at the SEAMCAP Meeting and its staff members who were involved in this project.

I am hopeful that the efforts of all these committed people will provide a richer, more accurate information base for conserving the endangered environment of Nepal and the mountains of the $\mathrm{HKH}$ and allow Nepal to participate effectively in the global environment agenda.

J. Gabriel Campbell

Director General

International Centre for Integrated Mountain Development

Kathmandu

March 2001 


\section{Acknowledgements}

UNEP would like to thank the many individuals and institutions who have contributed to the preparaton of Nepal: State of the Environment 2001. They included individuals in government departments, intergovernmental organisations, academic institutions, and voluntary organisations. A full list of contributors, reviewers, and participants of the national State of the Environment training and consultation are included in the Annexes. Special thanks are extended to the following institutions.

National Implementing Agency

Ministry of Population and Environment (MoPE), Nepal

National Collaborating Centre

International Centre for Integrated Mountain Development (ICIMOD), Nepal

\section{Funding}

The Norwegian Agency for Development Cooperation (NORAD) provided the financial support needed to the Strengthening Environmental Assessment and Monitoring Capabilities in South Asia and Greater Mekong Subregion (SEAMCAP) Project under which Nepal: State of the Environment 2001 has been prepared.

SEAMCAP Project Facilitator

Raghunathan Rajamani

Project Leader at National Level

Bandana Kayastha Pradhan

\section{Editors}

Peter Edwards

Greta Rana

A. Beatrice Murray Shrestha

\section{SEAMCAP Project Team}

UNEP RRC.AP

Surendra Shrestha

Choudhury Rudra Charan Mohanty

May Ann Mamicpic-Bernardo

Mylvakanam Iyngararasan

Purna Chandra Lall Rajbhandari
SACEP

Ananda Raj Joshi

Pradyumna Kumar Kotta 


\section{Acronyms and Abbreviations}

$\begin{array}{ll}\text { ADB } & \text { Asian Development Bank } \\ \text { AEPC } & \text { Alternative Energy Promotion Centre } \\ \text { AIC } & \text { Agricultural Inputs Corporation } \\ \text { AIT } & \text { Asian Institute of Technology } \\ \text { APP } & \text { Agricultural Prospective Plan } \\ \text { APROSC } & \text { Agricultural Projects Services Centre } \\ \text { ARI } & \text { acute respiratory infection } \\ \text { ASD } & \text { Agricultural Statistics Division } \\ & \\ \text { BHC } & \text { benzene hexachloride } \\ \text { BOD } & \text { biological oxygen demand } \\ \text { BOD } & \text { biological oxygen demand (5 days) } \\ \text { BPP } & \text { Biodiversity Profile Project } \\ & \\ \text { CBO } & \text { community-based organisation } \\ \text { CBS } & \text { Central Bureau of Statistics } \\ \text { CDG } & \text { Central Department of Geography } \\ \text { CDR } & \text { Central Development Region } \\ \text { CEDA } & \text { Centre for Economic Development and Administration } \\ \text { CFC-12 } & \text { chloroflurocarbon } \\ \text { CITES } & \text { Convention on International Trade in Endangered Species of Wild Fauna and } \\ & \text { Flora } \\ \text { COD } & \text { chemical oxygen demand } \\ & \\ \text { DDC } & \text { district development committee } \\ \text { DFI } & \text { district forest inventory } \\ \text { DFRS } & \text { Department of Forest Research and Survey } \\ \text { DHM } & \text { Department of Hydrology and Meteorology } \\ \text { DHS } & \text { Department of Health Services } \\ \text { DMG } & \text { Department of Mines and Geology } \\ \text { DNPWC } & \text { Department of National Parks and Wildlife Conservation } \\ \text { DISCO } & \text { District Soil Conservation Office } \\ \text { DO } & \text { dissolved oxygen } \\ \text { DoA } & \text { Department of Agriculture } \\ \text { DoC } & \text { Department of Customs } \\ \text { DoF } & \text { Department of Forests } \\ \text { DoF } & \text { Department of Finance } \\ \text { DoHS } & \text { Department of Health Services } \\ \text { DoI } & \text { Department of Irrigation } \\ & \\ & \end{array}$


DoR

DPR

DPTC

DSCWM

$\begin{array}{ll}\text { ECOS } & \text { Environmental Conservation through Educatio } \\ \text { EDR } & \text { Eastern Development Region } \\ \text { EIA } & \text { environmental impact assessment } \\ \text { ENPHO } & \text { Environment and Public Health Organisation } \\ \text { ESPS } & \text { Environment Sector Programme Support } \\ \text { EPA } & \text { Environmental Protection Act } \\ \text { EPC } & \text { Environmental Protection Council } \\ \text { EPR } & \text { Environmental Protection Rule } \\ \text { EURO-1 } & \text { European Standard One }\end{array}$

FINNIDA

FSD

GDP

GEO

GHG

GIS

GLOF

GTZ

GWRDP

$\mathrm{HC}$

$\mathrm{HCFC}$

HMG

HMGN

HOPE

HSD

HSU

HVS

ICS

ICIMOD

IEC

INGO

IPCC

ITTA

IUCN

JEC

KMC

KVVECP

LEADERS

LPG

LRMP liquefied petroleum gas

Land Resources Mapping Project
Department of Roads

Department of Plant Resources

Disaster Prevention Technical Centre

Department of Soil Conservation and Watershed Management

Environmental Conservation through Education and Research

Eastern Development Region

Environment and Public Health Organisation

Environment Sector Programme Support

European Standard One

Finnish International Development Agency

Forest Survey Division

gross domestic product

Global Environment Outlook

greenhouse gas

geographic information systems

glacial lake outburst flood

German Agency for Technical Co-operation

Groundwater Resource Development Project

hydrocarbon

hydro-chlorofluorocarbon

His Majesty's Government

His Majesty's Government of Nepal

Hidden Opportunities for Productivity and Environment

high speed diesel

Hartridge smoke unit

high volume sampler

improved cooking stove

International Centre for Integrated Mountain Development

information, education, and communication

international government organisation

Intergovernmental Panel on Climate Change

International Tropical Timber Agreement

International Union for Conservation of Nature

Japan Environment Corporation

Kathmandu Metropolitan City

Kathmandu Valley Vehicular Emission Control Programme

Legal and Environmental Analysis and Development Research 
MENRIS Mountain Environment and Natural Resources Information System

MFSC Ministry of Forest and Soil Conservation

MHPP

MLD

Ministry of Housing and Physical Planning

MNR Ministry of Local Development

MoA

Mountain Natural Resources

$\mathrm{MoE}$

$\mathrm{MoF}$

Ministry of Agriculture

$\mathrm{MoH}$

Ministry of Education

MoHA

MoI

Ministry of Finance

MoPE

Ministry of Health

MoWR

MPFS

Ministry of Home Affairs

MUAN

Ministry of Industry

MWDR

Ministry of Population and Environment

NAA

Ministry of Water Resources

NARC

Master Plan for the Forestry Sector

Municipal Association of Nepal

\section{NARMSAP}

Mid-Western Development Region

NBSM

NEA

Nepal Agricultural Association

NECG

Nepal Agricultural Research Council

NEPAP

NESS

NFI

NGO

NHDR

NOC

NORAD

NPC

NSIC

NTFP

NTU

NVMES

Natural Resource Management Sector Assistance Programme

NWSC

Nepal Bureau of Standards and Metrology

Nepal Electricity Authority

Nepal Environment Conservation Group

Nepal Environmental Policy and Action Plan

Nepal Environmental and Scientific Services

ODS

National Forest Inventory

non-government organisation

Nepal Human Development Report

OPD

Nepal Oil Corporation

Norwegian Agency for Cooperation and Development

National Planning Commission

Nepal Standard of Industrial Classification

non-timber forest product

nephelometer turbidity unit

Nepal Vehicular Mass Emission Standard

Nepal Water Supply Corporation

PAH

PARDYP

ozone depleting substance

outpatients department

poly aromatic hydrocarbon

People and Resource Dynamics in Mountain Watersheds of the Hindu KushHimalayas

RWSSP Rural Water Supply and Sewerage Project

SACEP

South Asia Co-operative Environment Programme

SEAMCAP Strengthening Environmental Assessment and Monitoring Capabilities in South

Asia and the Greater Mekong 

significant environmental issues

SIDA

SoE

SWMRMC

TDFB

TDN

TDS

TFR

TPC

TSP

TSS

TU

UBC

UDLE

UNDP

UNEP/EAP-APUnited Nations Environment Programme/Environmental Assessment Programme for Asia and the Pacific

UNICEF United Nations Children's Fund

URBAIR Urban Air Quality Management Strategy in Asia

URTI upper respiratory tract infection

USEPA

VDC village development committee

VOC volatile organic matter

WDR Western Development Region

WECS Water and Energy Commission Secretariat

WHO World Health Organisation 


\section{Symbols and}

Units

Symbol (Chemical)

As arsenic

C carbon

$\mathrm{CH}_{4}$ methane

$\mathrm{Cl}^{4}$ chloride ion

$\mathrm{CO}$ carbon monoxide

$\mathrm{CO}_{2}$ carbon dioxide

$\mathrm{O}_{2}$ oxygen (gas)

$\mathrm{O}_{3} \quad$ ozone

$\mathrm{N}$ nitrogen

$\mathrm{NO}_{2}$ nitrogen dioxide

$\mathrm{NO}_{x}$ oxides of nitrogen

P phosphorus

$\mathrm{Pb}$ lead

$\mathrm{S} \quad$ sulphur

$\mathrm{SO}_{2} \quad$ sulphur dioxide

$\mathrm{SO}_{\mathrm{x}}$ sulphur oxide

Units and Symbols

$\mathrm{cm} \quad$ centimetre

$\mathrm{db} \quad$ decibel

$\begin{array}{ll}\text { g } & \text { gram } \\ \text { Gj } & \text { gigajoule }\end{array}$

h hour

$\mathrm{kg} \quad$ kilogramme

kgoe kilogramme oil equivalent

$\mathrm{km} \quad$ kilometre

kj kilojoule 


$\begin{array}{ll}\text { l } & \text { litre } \\ \mathrm{m} & \text { litre consumption per day } \\ \mathrm{m} & \text { metre } \\ \mathrm{masl} & \text { metres above sea level } \\ \mathrm{ml} & \text { millilitre } \\ \mathrm{mld} & \text { million litres per day } \\ \mathrm{m}^{3} & \text { cubic metres } \\ \mathrm{mg} & \text { milligram } \\ \mu \mathrm{g} & \text { microgram } \\ \mathrm{pH} & \text { hydrogen-ion concentration } \\ \mathrm{ppm} & \text { parts per million } \\ \mathrm{PM}-10 & \text { particulate matter } \leq 10 \mu \mathrm{m} \text { diameter } \\ & \\ \text { toe } & \text { tonnes of oil equivalent }\end{array}$




\section{Notes}

\section{Exchange rate}

Values in Nepalese rupees have been converted to US\$ at the exchange rates shown

Exchange (buying) rate for 1 US dollar (average for the year)

Year

198919901991199219931994199519961997199819992000

$\begin{array}{lllllllllllll}\text { Nepali rupees (NRs) } & 27.4 & 29.1 & 42.7 & 42.6 & 49 & 49.1 & 50.5 & 56.3 & 56.8 & 67.6 & 68.2 & 70.5\end{array}$

\section{Dates}

Annual data for Nepal are sometimes collected according to the Gregorian calendar (January to December) but often according to the Nepali calendar (Bikram Sambat, which runs from approximately 15th April to 14 April the following year). In the latter case, year dates are given in the form 1978/79 and so on. 


\section{Table of Contents}

Foreword (Executive Director, UNEP)

Foreword (Secretary, MoPE, Nepal)

Foreword (Director General, ICIMOD)

Acknowledgements

Acronyms and Abbreviations

Symbols and Units

Notes

Part I: Executive Summary

1.1 General Background of the Report

1.2 Overview of Major Environmental Developments and Trends 3

1.3 Key National Environmental Issues

1.3.1 Forest depletion

1.3.2 Soil degradation

1.3.3 Solid waste management

1.3.4 Water quality

1.3.5 Air pollution

Conclusion

Part II: Overview of Major Environmental Developments and Trends

2.1 Background

2.1.1 Nepal

2.1.2 The State of the Environment Report

2.2 Environmental Conditions

2.2.1 Land

2.2.2 Water

2.2.3 Forest

2.2.4 Forest fire

2.2.5 Biodiversity

2.2.6 Atmosphere and climate $\quad 21$

2.2.7 Solid waste $\quad 22$

2.2.8 Transboundary movement of wastes $\quad 22$

2.2.9 Glacial lake outburst flood events $\quad 35$

2.2.10 Noise pollution $\quad 35$

2.2.11 Food security 36 
2.3 Social and economic driving forces 36

2.3.1 Population $\quad 36$

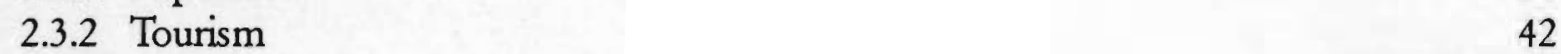

$\begin{array}{lll}2.3 .3 \text { Roads } & 45\end{array}$

$\begin{array}{lll}\text { 2.3.4 Health services status } & 46\end{array}$

2.3.5 Pattern of accessibility to basic facilities $\quad 47$

$\begin{array}{ll}\text { 2.4 Prioritisation of significant environmental issues } & 48\end{array}$

$\begin{array}{ll}\text { References } & 48\end{array}$

Part III: Key Issues

3.1 Forest Depletion $\quad 53$

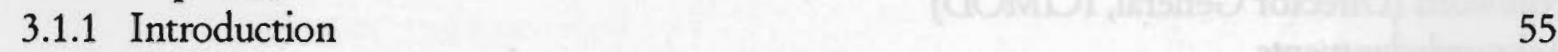

$\begin{array}{lll}3.1 .2 & \text { Pressure } & 55\end{array}$

$\begin{array}{lll}3.1 .3 \text { State } & 57\end{array}$

3.1.4 Impacts 63

$\begin{array}{lll}3.1 .5 & \text { Responses } & 70\end{array}$

$\begin{array}{ll}3.1 .6 \text { Conclusion } & 73\end{array}$

$\begin{array}{ll}\text { 3.1.7 Proposed Projects } & 74\end{array}$

$\begin{array}{ll}\text { References } & 75\end{array}$

$\begin{array}{ll}3.2 \text { Soil Degradation } & 79\end{array}$

$\begin{array}{lll}3.2 .1 & \text { Introduction } & 81\end{array}$

$\begin{array}{ll}3.2 .2 \text { Pressure } & 81\end{array}$

$\begin{array}{lll}3.2 .3 \text { State } & 84\end{array}$

$\begin{array}{lll}3.2 .4 & \text { Impacts } & 85\end{array}$

$\begin{array}{lll}3.2 .5 & \text { Responses } & 86\end{array}$

$\begin{array}{ll}3.2 .6 \text { Conclusion } & 90\end{array}$

$\begin{array}{lll}\text { 3.2.7 Proposed Project } & 93\end{array}$

$\begin{array}{ll}\text { References } & 94\end{array}$

$\begin{array}{lr}3.3 \text { Solid Waste Management } & 97\end{array}$

3.3.1 Introduction $\quad 99$

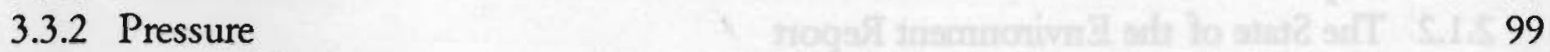

$\begin{array}{ll}\text { 3.3.3 State and Impacts } & 101\end{array}$

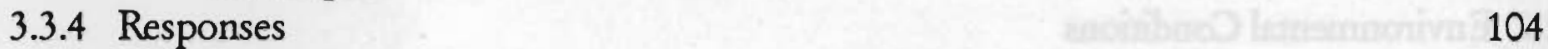

3.3.5 Conclusion 112

3.3.6 Proposed projects $\quad 114$

$\begin{array}{lr}\text { References } & 117\end{array}$

3.4 Water Quality 119

$\begin{array}{ll}3.4 .1 \text { Introduction } & 121\end{array}$

3.4.2 Pressure $\quad 121$

3.4.3. State $\quad 128$

$\begin{array}{ll}3.4 .4 \text { Impacts } & 135\end{array}$

3.4.5 Responses $\quad 141$ 
3.4.7 Proposed projects

References

3.5 Air Pollution

3.5.1 Introduction

3.5.2 Pressure

153

3.5.3 State

156

3.5.4 Impacts

3.5.5 Responses

163

3.5.6 Conclusion

166

3.5.7 Proposed projects

167

References

4.1 Conclusions

175

4.1.1 Forest depletion

175

4.1.2 Soil degradation

176

4.1.3 Solid waste management

176

4.1.4 Water quality

178

4.1.5 Air pollution

178

4.2.1 Emerging issues

180

4.2.2 Future challenges

180

4.2.3 Recommendations

Annexes

181

Back Pocket

Transparent pullout sheet, outline map of Nepal with district names and boundaries, to use as an overlay with maps 